\title{
Analisis Jumlah Kadar Hemoglobin Dan Sel Darah Putih (Leukosit) Pada Mencit (Mus Musculus) Sebelum Dan Sesudah Radiasi Gamma Co-60 Dengan Berbagai Variasi Dosis
}

\author{
Yulita wulandari $^{1}$, Puji Hartoyo ${ }^{1}$, Febria Anita ${ }^{1}$, Purwantiningsih ${ }^{1}$ \\ ${ }^{1}$ Program Studi Fisika, Universitas Nasional, Jalan Sawo Manila, Pejaten, Pasar Minggu \\ Jakarta Selatan 12520 \\ Email: febria.anita85@gmail.com
}

\begin{abstract}
ABSTRAK. Radiasi diketahui mempunyai efek merusak sel-sel induk dan sel-sel prekursor pada sumsum tulang (sindrom sumsum tulang), sehingga menurunkan jumlah sel-sel darah dalam peredarannya.Dalam kondisi normal, kehilangan komponen sel darah akibat konsumsi makanan, infeksi maupun umur dapat diimbangi oleh produksi sel darah induk dalam sumsum tulang. Radiasi dapat menghambat aktivitas sel darah induk atau menghentikan aktivitasnya sama sekali, tergantung pada dosis radiasi yang diterimanya. Selain itu sel darah yang bersirkulasi akan mengalami kematian interfase. Dengan demikian, radiasi akan menurunkan jumlah sel darah yang bergantung pada radiosensitivitas dan harapan hidup sel. Telah dilakukan penelitian respon adaptasi pada 30 ekor mencit jantan berumur 37 - 46 hari, dengan berat dalam rentang $23.79-26.66$ gram. Sampel mencit dibagi menjadi 10 kelompok, tiap kelompok terdiri dari 3 mencit yang diberi perlakuan penyinaran dengan radiasi gamma Co-60, mencit diberi dosis tunggal 0,5 Gy, 1 Gy, 1,5 Gy, 2 Gy, 2,5 Gy, 3 Gy, 3,5 Gy, 4 Gy, 4,5 Gy dan 5 Gy. Sampel darah mencit diambil sebelum dan sesudah penyinaran.Sampel yang diambil berupa hemoglobin dan leukosit. Jumlah hemoglobin rata-rata mencit $12,899 \mathrm{~g} / \mathrm{dl}$ sebelum radiasi dan 12,154 $\mathrm{g} / \mathrm{dl}$ sesudah radiasi dengan variasi dosis 0,5 Gy hingga $5 \mathrm{~Gy}$. Jumlah leukosit rata-rata mencit $8,462 \times 10^{3} / \mu \mathrm{l}$ sebelum radiasi dan $7,207 \times 10^{3} / \mu 1$ sesudah radiasi dengan variasi dosis 0,5 Gy hingga 5 Gy.
\end{abstract}

Kata Kunci: Radiasi, respon darah, variasi dosis, hemoglobin, mencit.

\begin{abstract}
Radiation is known to have the effect of damaging the stem cells and precursor cells in the bone marrow (bone marrow syndrome), thus lowering the number of blood cells in its release. Under normal conditions, loss of blood cell components due to food consumption, infection and age can be offset by the parent blood cell production in the bone marrow. Radiation can inhibit the activity of stem cells or terminate its activities at all, depending on the dose of radiation received. In addition to the circulating blood cells will experience death interfase. Thus, the radiation would decrease the number of blood cells that depend on the radiosensitivitas and life expectancy has done research cells. Response adaptation in 30 tail mice males aged $37-46$ days, weighing in the range of 23.79 - 26.66 grams. Samples of the mice are divided into 10 groups, each group consists of 3 mice who were given the treatment shines with Co-60 gamma radiation, mice were given a single dose of $0.5 \mathrm{~Gy}, 1 \mathrm{~Gy}, 1.5 \mathrm{~Gy}, 2 \mathrm{~Gy}, 2.5 \mathrm{~Gy}, 3 \mathrm{~Gy}, 3.5 \mathrm{~Gy}, 4 \mathrm{~Gy}, 4.5 \mathrm{~Gy}$ and 5 Gy. Blood samples taken before and after the mice are very. Samples were taken in the form of hemoglobin and leukocytes. The amount of hemoglobin average house mouse $12,899 \mathrm{~g} / \mathrm{dl}$ before radiation and $12,154 \mathrm{~g} / \mathrm{dl}$ after the radiation dose of $0.5 \mathrm{~Gy}$ with variations up to $5 \mathrm{~Gy}$. The amount of the average house mouse leukocytes 8,462 $\times 10^{3} / \mu \mathrm{l}$ before radiation and 7,207 $\times 10^{3} / \mu \mathrm{l}$ after the radiation dose of $0.5 \mathrm{~Gy}$ with variations up to 5 Gy.
\end{abstract}

Keywords: Radiation, blood response, dose variation, hemoglobin, house mouse

\section{PENDAHULUAN}

Radiasi banyak dimanfaatkan dalam kehidupan sehari-hari terutama untuk keperluan diagnostik dan terapi.Pemanfaatan radiasi pengion perlu mendapatkan perhatian yangkhusus, mengingat 
radiasi yang bermanfaat dan dimanfaatkan tersebut ternyata membawa pengaruh yang kurang baik bagi penggunanya. Jika radiasi mengenai tubuh manusia, kemungkinan yang dapat terjadi adalah radiasi akan berinteraksi dengan tubuh manusia. Sebagian besar radiasi berinteraksi dengan atom-atom hidrogen sebagai pembentuk air dan dalam hitungan waktu sangat cepat yaitu kurang dari $10^{-16}$ detik hingga terjadi ionisasi yang merupakan awal dari perubahan kimiawi yang kemudian dapat mengakibatkan efek biologis yang merugikan, yaitu mengakibatkan terjadinya ionisasi dan menghasilkan radikal bebas, misalnya radikal bebas hidroksil $(\mathrm{OH})$, yang terdiri dari atom oksigen dan atom hidrogen. Secara kimia, radikal bebas sangat reaktif dan dapat mengubah molekul-molekul penting dalam sel [1].

Setiap organ tubuh umumnya tersusun dari jaringan yang merupakan kumpulan dari sejumlah sel yang mempunyai fungsi dan struktur yang sama. Selmempunyai inti sel. Sel terdiri dari $80 \%$ air dan 20\% senyawa biologis kompleks.Sel merupakan unit fungsional terkecil dalam tubuh karena dapat menjalankan fungsi hidup secara lengkap dan sempurna seperti melakukan pembelahan, pernapasan, pertumbuhan dan tanggapan terhadap rangsangan. Sel tubuh sangat bervariasi dalam bentuk, ukuran dan fungsinya. Tubuh manusia dewasa terdiri dari sekitar seratus trilliun sel dengan diameter rerata sekitar 10 mikrometer[1]. Sel pada dasarnya terdiri dari dua komponen utama yaitu sitoplasma dan inti sel (nucleus) yang keduanya dilindungi oleh suatu membran sel yangmemungkinkan terjadinya penerimaan dan pengiriman sinyal antar sel serta mengatur transportasi bahan-bahan keluar masuk sel. Komponen sel darah terdiri dari sel darah merah (eritrosit), sel darah putih (limfosit dan granulosit) dan sel keping darah (trombosit).

Pembentukan sel darah terletak pada sumsum tulang dan pada dosis sekitar 0,5 Gy pada sumsum tulang sudah dapat menyebabkan penekanan proses pembentukan komponen sel darah sehingga jumlahnya mengalami penurunan [2]. Jumlah sel limfosit menurun dalam waktu beberapa jam pasca paparan radiasi, sedangkan jumlah granulosit dan trombosit juga menurun tetapi dalam waktu yang lebih lama, beberapa hari atau minggu. Sementara penurunan jumlah eritrosit terjadi lebih lambat, beberapa minggu kemudian. Penurunan jumlah sel limfosit absolut atau total dapat digunakan untuk memperkirakan tingkat keparahan yang mungkin diderita seseorang akibat paparan radiasi akut.

Pada radiasi dengan dosis rendah yang mengenai sel darah, maka kemungkinan dapat memulihkan dirinya sendiri dengan sangat cepat. Namun bila dosis lebih tinggi, maka sel darah ada kemungkinantidak dapat memulihkan dirinya sendiri, sehingga mengalami kerusakan permanen atau mati. Sel darah yang mati relatif tidak berbahaya karena akan diganti dengan sel baru. Sel darah yangmengalami kerusakan permanen dapat menghasilkan sel yang abnormal ketika sel darah yang rusak tersebut membelah diri. Sel darah yang abnormal inilah yang akan meningkatkan risiko tejadinya kanker pada manusia akibat radiasi. Hal ini menunjukan bahwa efek radiasi terhadap tubuh manusia bergantung padaseberapa banyak dosis yang diberikan. Oleh karena itu, penulis akan menganalisis jumlah sel darah sebelum dan sesudah radiasi dengan berbagai variasi dosis gamma Co-60 terutama untuk perubahan jumlah hemoglobin darah dan sel darah putih (leukosit) dengan menggunakan hewan percobaan yaitu mencit (Mus Musculus).

\section{METODE DAN BAHAN}

Sinar gamma (dinotasikan dengan $\gamma$ ) adalah sebuah bentuk berenergi dari radiasi elektromagnetik yang diproduksi oleh radioaktivitas atau proses nuklir atau subatomik lainnya seperti penghancuran elektron-positron. Sinar gamma merupakan sebuah bentuk radiasi mengionisasi yang mempunyai daya tembus yang lebih tinggi dari radiasi alfa atau beta.Namun dari sifat ionisasi dari radiasi gamma memiliki jumlah lebih kecil dibanding radiasi alfa atau beta seperti pada Gambar 1. Radiasi gamma mempunyai sifat Radiasi dengan panjang gelombang pendek dan frekuensi tinggi. Tidak terbelokkan dalam medan magnet. Energi yang paling besar. Daya tembus terkuat yang tidak terlalu diperlukan. Teleterapi adalah istilah umum yang digunakan untuk penyinaran eksternal dengan sumber radiasi yang berada jauh atau mempunyai jarak dari pasien. Co-60 adalah salah satu sumber radiasi yang paling banyak 
digunakan untuk keperluan medis, terutama di Indonesia (50\%) sebagai sumber radiasi pesawat teleterapi. Menurut energinya telecobalt diklasifikasi sebagai pesawat megavoltage karena energi reratanya $1,25 \mathrm{MeV}$. Co-60 merupakan sumber radiasi gamma yang dihasilkan dari aktivitas Co-59 yang ditembakkan neutron dalam sebuah reaktor, sehingga menjadi radioaktif. Anak luruh dari Co-60 adalah Ni-60 yang disertai dengan pemancaran sinar $\beta$ dan dua sinar gamma dengan energi $1,17 \mathrm{MeV}$ dan 1,33 MeV, dengan waktu paruh 5,26 tahun atau konstanta peluruhan 0,011 bulan $^{-1}[3]$.

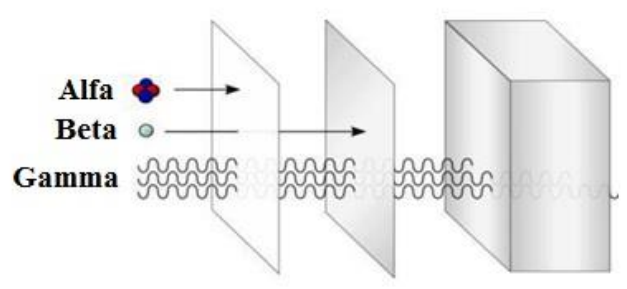

GAMBAR 1. Daya tembus radiasi sinar alfa, beta dan gamma [3].

Dalam menggunaan penyinaran eksternal (teleterapi Co-60) perlu diperhatikan beberapa parameter utama yaitu kedalaman, luas lapangan radiasi, teknik SSD atau SAD, dan energi foton.Lapangan radiasi yang digunakan untuk radioterapi mempunyai beberapa bentuk dan ukuran, disesuaikan dengan bentuk dan ukuran kanker atau tumor yang diobati.Secara umum lapangan radiasi dikelompokan menjadi bujur sangkar, persegi empat panjang, lingkaran dan lapangan tidak beraturan.

SSD (Source Surface Distance) adalah jarak antara sumber radiasi dengan permukaan objek (kulit). Pada radioterapi, SSD merupakan parameter yang sangat penting karena memberikan konstribusi terhadap besar dosis dan PDD (Percentage Depth Dose) pada umumnya dinormalisasikan dengan dosis maksimum $($ Dmaks $=100 \%$ ), yakni dosis pada kedalaman dmaks.

Dosis serap adalah jumlah energi yang diserahkan oleh radiasi atau banyaknya energi yang diserap oleh bahan persatuan massa bahan itu. Jadi, dosis serap merupakan ukuran banyaknya energi yang diberikan oleh radiasi pengion kepada medium.Satuan untuk dosis serap adalah Joule perkilogram-medium $\left(\mathrm{J}_{\mathrm{kg}}{ }^{-1}\right)$. Dalam sistem SI besaran dosis serap diberi satuan khusus, yaitu Gray (Gy). Persamaan dosis serap dijelaskan sebagai berikut [4]:

$$
D=\frac{d E}{d M}
$$

Dengan $D=$ Dosis serap $(\mathrm{J} / \mathrm{kg}), d E=$ Jumlah energi $(\mathrm{J}), d M=$ Massa medium $(\mathrm{kg})$.

Dosis ekivalen efektif atau yang bisa disebut dosis efektif.Hubungan antara peluang timbulnya efek biologi tertentu akibat penerimaan dosis ekivalen pada suatu jaringan bergantung pada organ atau jaringan yang tersinari. Untuk menunjukkan keefektifan radiasi dalam menimbulkan efek tertentu pada suatu organ diperlukan besaran baru yang disebut dosis efektif $\left(\mathrm{H}_{\mathrm{E}}\right)$. Besaran ini merupakan penurunan dari besaran dosis ekivalen yang dibobot. Dosis efektif dalam organ (T), yang menerima penyinaran dengan radiasi ekivalen ditentukan dengan persamaan (3) dan (4) sebagai berikut [4],

$$
\begin{aligned}
& H_{E}=\sum W_{T} \cdot W_{R} D \\
& H_{E}=\sum W_{R} \cdot H_{T R}
\end{aligned}
$$

Dengan $H_{E}$ : Dosis ekivalen efektif $(\mathrm{mSv}), D$ : Dosis serap (mGy), $H_{T R}$ : Dosis ekivalen organ yang menerima penyinaran $(\mathrm{mSv}), W_{R}$ : Bobot radiasi, $W_{T}$ : Bobot jaringan $(\mathrm{mSv})$.

Rumus persentase selisih jumlah hemoglobin dan leukosit sebelum dan sesudah penyinaran gamma Co-60 dengan variasi dosis dijelaskan seperti pada persamaan (5). 


$$
\mathrm{Z}=\frac{1}{H a}(H a-H b) \times 100
$$

Dengan : $Z=$ Persentase Selisih, $H_{a}=$ Rerata jumlah sel darah sebelum radiasi, $H_{b}=$ Rerata jumlah sel darah sesudah radiasi.

Mencit biasa digunakan sebagai hewan percobaan dilaboratorium. Pubertas terjadi pada umur 68 minggu. Sebagai hewan percobaan dilaboratorium, mencit dipelihara dalam kandang dalam bentuk kotak plastik dengan Alas kandang diberi sekam atau serutan kayu dengan temperatur 18 $-29^{\circ} \mathrm{C}$. Mencit laboratorium mempunyai berat badan kira-kira sama dengan mencit liar 30 - 40 gram, tetapi setelah diternakkan secara selektif [8]. Data biologis mencit normal ditunjukan pada lampiran. Untuk jumlah hemoglobin normal 13,4 g/dl dan jumlah leukosit normal 8,4 $\mathrm{x}$ $10^{3} / \mu 1[6]$.

\section{METODE DAN BAHAN}

Pada penelitian ini alat dan bahan yang digunakan adalah Pesawat teleterapi gamma Co-60 Theratron 780, Mencit 30ekor(umur : 37 hari, BB: 35-40 gr), Larutan EDTA (Ethylene Diamine Tetra Aceticacid), Jarum intradermal dan tabung darah, Alat hitung hemoglobin dan leukosit.

Proses radiasi dilakukan dengan memberikan dosis radiasi dari 0,5 Gy, 1Gy, 1,5 Gy, 2 Gy, 2,5 Gy, 3 Gy, 3,5 Gy, 4 Gy, 4,5 Gy dan 5 Gy. Setiap penyinaran dengan setiap variasi menggunakan 3 ekor mencit dan dilakukan selama satu hari dengan jumlah mencit keseluruhan yaitu 30 ekor. Kondisi penyinaran dengan SSD (source to surface distance) $80 \mathrm{~cm}$ pada permukaan $2 \mathrm{~cm}$ dari dasar kotak (lapangan $20 \times 10 \mathrm{~cm}$ ). Dosis radiasi dihitung pada kedalaman $4 \mathrm{~cm}$, seperti ditunjukan pada gambar 2. Setelah proses radiasi dilakukan, maka proses pengambilan darah dilakukan. Namun, sebelum proses radiasi, darah mencit juga diambil untuk bahan perbandingan.

Volume darah yang diperlukan untuk pemeriksaan kadar hemoglobin dan leukosithanya sedikit, darah dapat diambil melalui menyuntik vena ekor, memotong ujung ekor dan memotong jari kaki. Dalam penelitian ini pengambilan darah dipilih dengan penyuntikan vena dibagian ekor dengan memerlukan jarum intradermal yang sangat kecil sekali. Seringkali dengan jarum yang sangat kecil, darah dalam jarum menggumpal sebelum diperoleh cukup banyak darah. Maka ditambahkan cairan EDTA di jarumnya.

Ekor mencit didesinfektan dengan alkohol kemudian ekor tersebut disuntik dengan jarum intradermal steril. Untuk hitung jumlah kadar hemoglobin dan leukosit, darah didalam jarum dipindahkan ke tabung khusus darah.

\section{HASIL DAN PEMBAHASAN}

Data perhitungan jumlah hemoglobin sebelum dan sesudah mencit diradiasi dengan dosis 0,5 Gy, 1 Gy, 1,5 Gy, 2 Gy, 2,5 Gy, 3 Gy, 3,5 Gy, 4 Gy, 4,5 Gy dan 5 Gy dengan menggunakan gamma Co-60 ditunjukkan pada tabel 1 .

TABEL 1. Jumlah Hemoglobin Mencit Sebelum dan Sesudah Radiasi

\begin{tabular}{|c|c|c|c|c|}
\hline No. & $\begin{array}{c}\text { Dosis } \\
(\mathbf{G y})\end{array}$ & $\left(\mathbf{H}_{\boldsymbol{a}}\right)(\mathbf{g} / \mathbf{d l})$ & $\left(\mathbf{H}_{\boldsymbol{b}}\right)(\mathbf{g} / \mathbf{d l} \mathbf{l})$ & $\boldsymbol{\Delta H}$ \\
\hline 1 & 0,5 & 13,50 & 13,23 & 0,27 \\
\hline 2 & 1 & 12,33 & 11,97 & 0,36 \\
\hline 3 & 1,5 & 12,50 & 12,07 & 0,43 \\
\hline 4 & 2 & 12,50 & 12,00 & 0,50 \\
\hline 5 & 2,5 & 12,80 & 12,17 & 0,63 \\
\hline 6 & 3 & 13,33 & 12,67 & 0,66 \\
\hline 7 & 3,5 & 13,23 & 12,50 & 0,73 \\
\hline 8 & 4 & 13,00 & 12,13 & 0,87 \\
\hline 9 & 4,5 & 12,63 & 11,23 & 1,40 \\
\hline 10 & 5 & 13,37 & 11,57 & 1,80 \\
\hline
\end{tabular}


Dari data tabel 1 didapatkan grafik batang perbedaan antara jumlah hemoglobin sebelum dan sesudah mencit diradiasi dengan variasi dosis 0,5 Gy hingga 5 Gy. Grafik tersebut akan mempermudah dalam penglihatan perbedaan yang terjadi antara hemoglobin sebelum dan sesudah diradiasi. Dari rerata diperoleh rerata jumlah hemoglobin terbanyak sebelum radiasi terdapat pada dosis 6 dan dosis 7 .

Namun selisih terbesar terdapat didosis 10 yaitu 1,80. Untuk dosis 6 dan dosis 7 hanya 0,73 dan 0,87 . Untuk dosis yang lainnya rerata mendapat nilai berbeda pula namun stabil tidak berbeda sangat jauh, seperti dosis 2 dengan dosis 2,5 selisihnya 0,5 dan 0,63 . Ini membuktikan pengaruh dosis yang diberikan saat radiasi berlangsung.

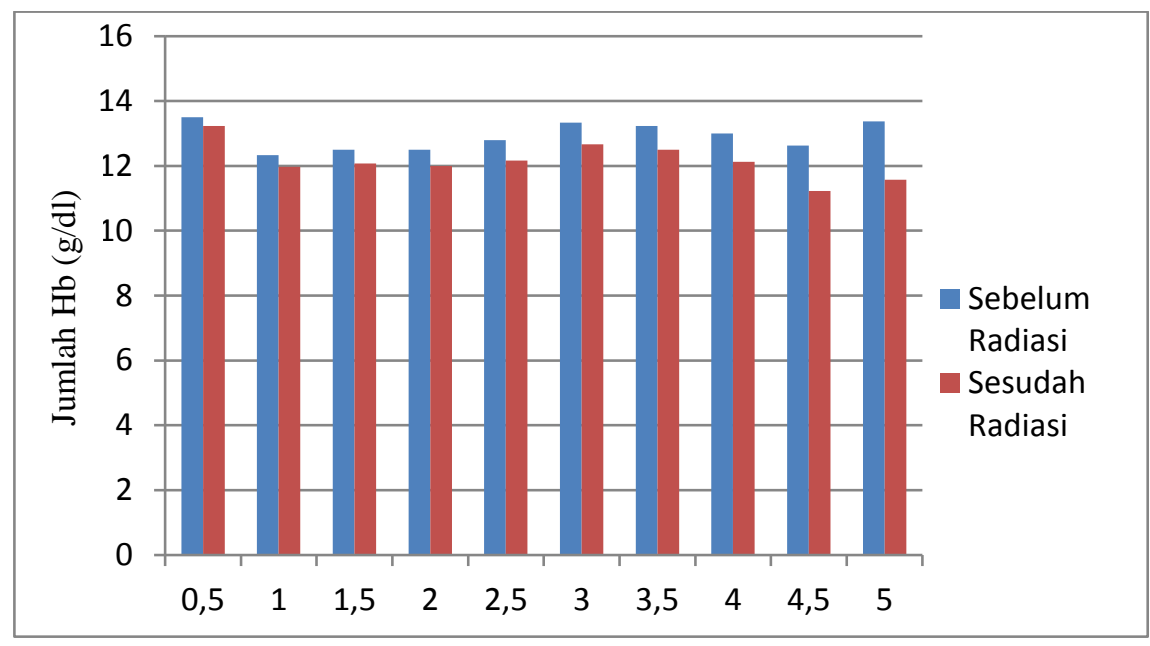

GAMBAR 2. Histogram Perbedaan Jumlah Hemoglobin Mencit Sebelum dan Sesudah Radiasi dengan Variasi dosis 0,5 Gy hingga 5 Gy

Pada gambar 2 dibuatkan histogram untuk memperjelas perbedaan jumlah hemoglobin dan leukosit sebelum dan sesudah radiasi. Tampak secara umum jumlah hemoglobin menurun dengan kenaikan dosis radiasi yang diberikan pada mencit. Apabila dibandingkan dengan grafik sebelum radiasi, hasil sesudah diradiasi untuk semua dosis radiasi menunjukkan penurunan jumlah hemoglobin.

TABEL 2. Persentase Penurunan Rerata Jumlah Hemoglobin Sebelum dengan Sesudah Radiasi

\begin{tabular}{|c|c|c|}
\hline No. & $\begin{array}{c}\text { Dosis } \\
(\mathbf{G y})\end{array}$ & $\begin{array}{c}\text { Persentase Penurunan Hb } \\
(\boldsymbol{\%})\end{array}$ \\
\hline 1 & 0,5 & 2,00 \\
\hline 2 & 1 & 2,92 \\
\hline 3 & 1,5 & 3,44 \\
\hline 4 & 2 & 4,00 \\
\hline 5 & 2,5 & 4,91 \\
\hline 6 & 3 & 4,95 \\
\hline 7 & 3,5 & 5,52 \\
\hline 8 & 4 & 6,69 \\
\hline 9 & 4,5 & 11,08 \\
\hline 10 & 5 & 13,46 \\
\hline
\end{tabular}

Dari Tabel 2 didapatkan fluktasi penurunan jumlah hemoglobin terbesar di 13,46\% didosis 5 Gy. Penurunan jumlah hemoglobin setiap 0,5 Gy penyinaran memiliki perbedaan, tidak terjadi kstabilan nilai penurunan di setiap pemberian penambahan atau pengurangan $0,5 \mathrm{~Gy}$. Penurunan tinggi berada dipemberian dosis 4 Gy dan 4,5 Gy hingga menghasilkan selisih 4,39\%. Ketidakstabilan disebabkan berbagai hal dan akan dibahas di pembahasan. Dan dari Tabel 2 didapatkan grafik kurva yang tidak linear karena penurunan yang tidak sama setiap pemberian 
penambahan dosis $0,5 \mathrm{~Gy}$.

Berikut grafik kurva persentase penurunan jumlah hemoglobin sebelum dan sesudah radiasi seperti gambar 3 di bawah ini.

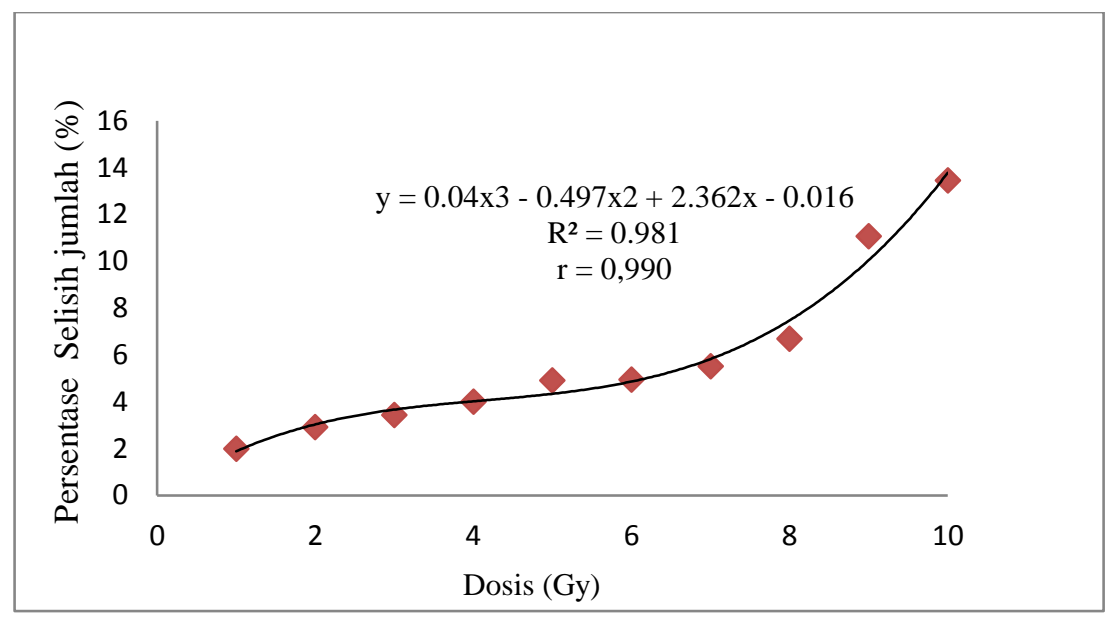

GAMBAR 3. Persentase PenurunanJumlah Hemoglobin

Gambar 3 menjelaskan persentase penurunan hemoglobin sebelum dan sesudah diradiasi, sehingga didapatkan acuan sebagai berikut : $\mathrm{y}=0,04 \mathrm{x}^{3}-0,497 \mathrm{x}^{2}+2,362 \mathrm{x}-0,016$ dengan $r=$ 0,990 . Nilai $r$ menunjukkan bahwa hubungan pemberian dosis radiasi terhadap penurunan jumlah hemoglobin sangat kuat. Nilai $y$ merupakan persentase selisih jumlah hemoglobin dalam persen dan nilaix merupakan dosis yang diberikan.Setiap 0,5 Gy dosis yang diberikan terjadi penurunan jumlah hemoglobin. Penurunan terbanyak terjadi pada dosis 5 Gy. Penurunan tidak stabil terjadi di dosis 3 Gy hingga 5 Gy.

Berikutnya data hasil perhitungan jumlah leukosit sebelum dan sesudah mencit diradiasi 0,5 Gy, 1 Gy, 1,5 Gy, 2 Gy, 2,5 Gy, 3 Gy, 3,5 Gy, 4 Gy, 4,5 Gy dan 5 Gy pada pesawat teleterapi gamma Co-60.

Ditunjukkan pada tabel 3 jumlah leukosit terjadi penurunan yang signifikan dibanding jumlah hemoglobin. Pada leukosit sama halnya dengan hemoglobin, walau jumlah leukosit yang reratanya terbanyak sebelum radiasi yaitu didosis 6 dan dosis 7, namun selisih jumlah penurunan mereka tidak terlalu besar seperti dosis berikutnya, yaitu dosis 8 , dosis 9 dan dosis 10.

TABEL 3. Jumlah Leukosit Mencit Sebelum dan Sesudah Radiasi

\begin{tabular}{|r|c|c|c|c|}
\hline \multicolumn{1}{|c|}{ No. } & Dosis $(\mathbf{G y})$ & $\left(\mathbf{L}_{\boldsymbol{a}}\right) \mathbf{( g / \mathbf { d l } )}$ & $\left(\mathbf{L}_{\boldsymbol{b}}\right) \mathbf{( g / d \mathbf { l } )}$ & $\boldsymbol{\Delta} \boldsymbol{L}$ \\
\hline 1 & 0,5 & 8,36 & 8,13 & 0,23 \\
\hline 2 & 1 & 8,43 & 7,87 & 0,56 \\
\hline 3 & 1,5 & 8,50 & 7,67 & 0,83 \\
\hline 4 & 2 & 8,47 & 7,53 & 0,94 \\
\hline 5 & 2,5 & 8,40 & 7,40 & 0,63 \\
\hline 6 & 3 & 8,53 & 7,40 & 0,66 \\
\hline 7 & 3,5 & 8,53 & 7,13 & 0,73 \\
\hline 8 & 4 & 8,50 & 6,87 & 0,87 \\
\hline 9 & 4,5 & 8,37 & 6,20 & 1,40 \\
\hline 10 & 5 & 8,53 & 5,87 & 1,80 \\
\hline
\end{tabular}

Salah satu penyebab jumlah leukosit turun cepat dibanding jumlah hemoglobin ialah tingkat sensitifitas leukosit terhadap radiasi yang sangat tinggi. Oleh sebab itu, jumlah leukosit bisa turun lebih banyak. Berikut histogram pada gambar 4 perbedaan antara jumlah leukosit sebelum dan sesudah diradiasi. 


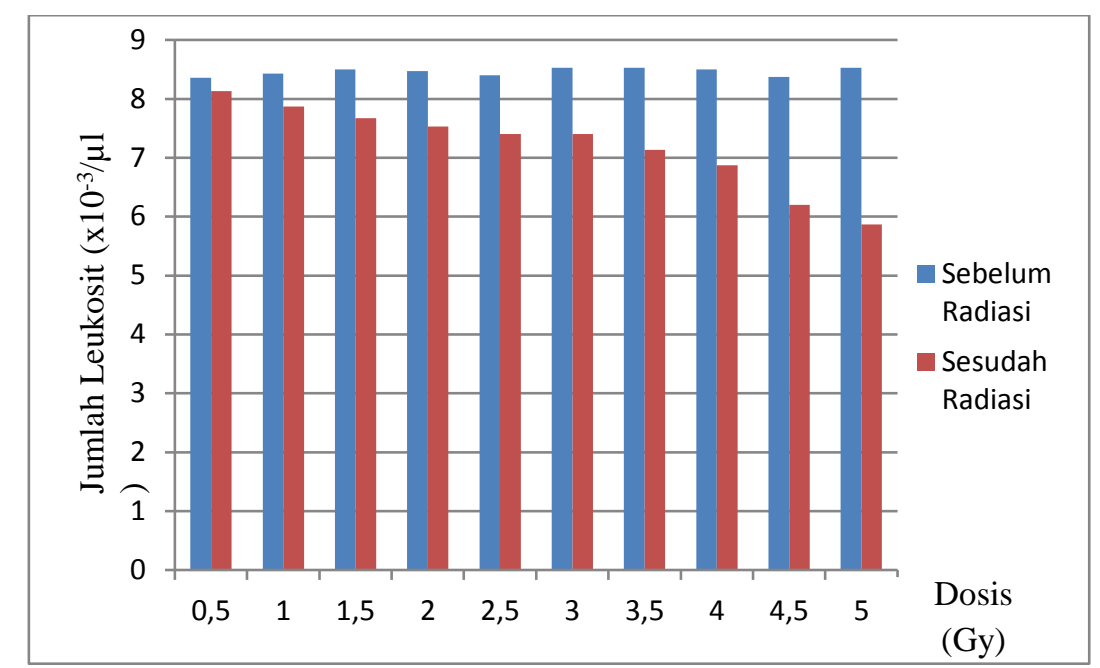

GAMBAR 4. Histogram Perbedaan Jumlah Leukosit Mencit Sebelum dan Sesudah Radiasi dengan Variasi dosis 0,5 Gy hingga 5 Gy

Tabel 4 yang merupakan hasil pengurangan jumlah leukosit sebelum dan sesudah radiasi yang dipersentasikan.

TABEL 4. Persentase Penurunan Rerata Jumlah Leukosit Sebelum dengan Sesudah Radiasi

\begin{tabular}{|c|c|c|}
\hline No. & Dosis $(\mathbf{G y})$ & Persentase Penurunan Leu (\%) \\
\hline 1 & 0,5 & 2.75 \\
\hline 2 & 1 & 6.64 \\
\hline 3 & 1,5 & 9.76 \\
\hline 4 & 2 & 11.10 \\
\hline 5 & 2,5 & 11.90 \\
\hline 6 & 3 & 13.25 \\
\hline 7 & 3,5 & 16.41 \\
\hline 8 & 4 & 19.18 \\
\hline 9 & 4,5 & 25.93 \\
\hline 10 & 5 & 31.18 \\
\hline
\end{tabular}

Dari tabel 4 didapatkan grafik kurva persentase selisih jumlah leukosit yang sangat berbeda dari persentase penurunan hemoglobin. Grafik kurva dapat dilihat di Gambar 5 sebagai berikut.

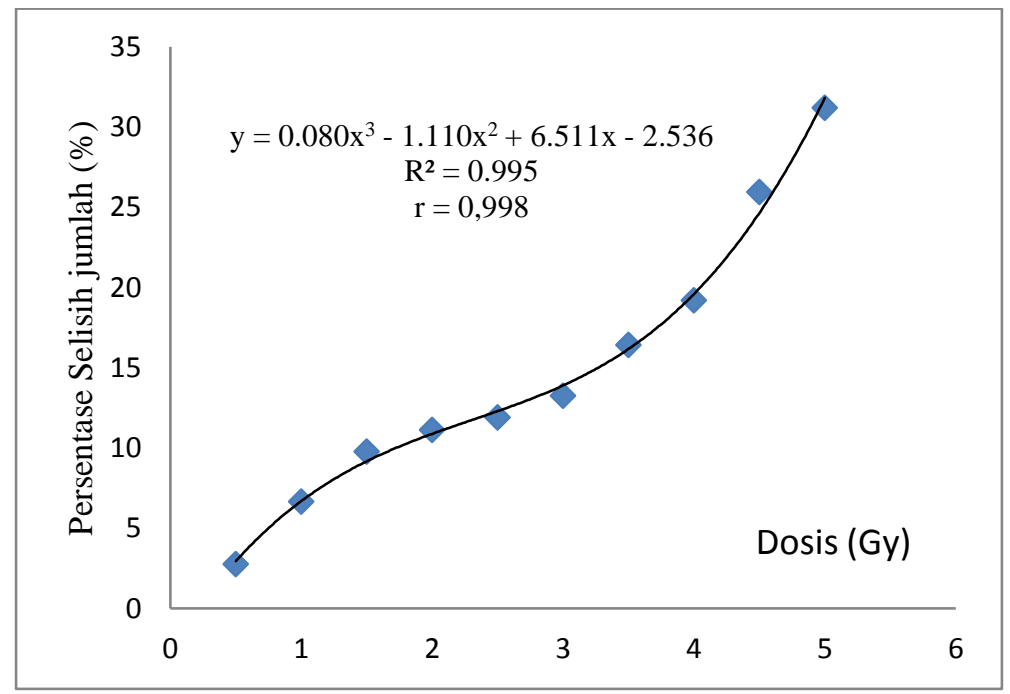

GAMBAR 5 Persentase Selisih Jumlah Leukosit. 
Selisih terbanyak terdapat dipemberian dosis 5 Gy, yaitu 2,66. Dan selisih terendah terdapat pada dosis 0,5 Gy. Selisih pada jumlah leukosit berbeda -beda disebabkan berbagai hal. Selisih stabil berada di 1,5 Gy hingga 3 Gy. Pada leukosit sama halnya dengan hemoglobin , walau jumlah leukosit yang reratanya terbanyak sebelum radiasi yaitu didosis 6 dan dosis 7 , namun selisih jumlah penurunan mereka tidak terlalu besar seperti dosis berikutnya, yaitu dosis 8 , dosis 9 dan dosis 10 .

Dari grafik kurva yang didapat pada gambar 5 tidak terjadi kurva linear pada dosis 2 Gy hingga 3,5 Gy. dan selisih persentase terbesar terdapat pada dosis 4 Gy dengan 4,5 Gy yaitu hingga $6,75 \%$. Untuk selisih persantese terkecil terdapat antara 2 Gy dengan 1,5 Gy yaitu 1,34 \%. Untuk persamaan regresi diperoleh sebagai berikut :

$\mathrm{y}=0,080 \mathrm{x}^{3}-1,110 \mathrm{x}^{2}+6,511 \mathrm{x}-2,536$ dengan $r=0,998$

$r$ menunjukkan bahwa hubungan pemberian dosis radiasi terhadap penurunan jumlah leukosit sangat kuat, $y$ merupakan persentase selisih jumlah hemoglobin dalam persen dan $x$ merupakan dosis yang diberikan.

\section{PEMBAHASAN}

Penyinaran dilakukan menggunakan metode dosis tunggal, jadi hanya sekali penyinaran dengan dosis yang telah ditentukan, yaitu 0,5 Gy, $1 \mathrm{~Gy}, 1,5 \mathrm{~Gy}, 2 \mathrm{~Gy}, 2,5 \mathrm{~Gy}, 3 \mathrm{~Gy}, 3,5 \mathrm{~Gy}, 4 \mathrm{~Gy}, 4,5$ Gy dan 5 Gy. Setelah penyinaran dilakukan pengambilan darah yang kedua yaitu setelah diradiasi, pengambilan diambil dalam jangka waktu 24 jam setelah penyinaran, untuk mengetahui perubahan yang terjadi setelah penyinaran. Dalam jangka waktu tersebut, mencit diberikan perlakuan sama dan diberi makan serta minum. Karena mencit cepat lapar.

Dari hasil yang didapat, terjadi perbedaan antara hasil sebelum dan sesudah radiasi. Terjadi penurunan jumlah hemoglobin dan leukosit. Semakin banyak dosis yang diberikan, semakin besar penurunan yang terjadi. Hasil pengambilan sample penelitian diperoleh jumlah hemoglobin rerata mencit $(12,899 \mathrm{~g} / \mathrm{dl})$ sebelum radiasi dan $(12,154 \mathrm{~g} / \mathrm{dl})$ sesudah radiasi dengan variasi dosis 0,5 Gy hingga 5 Gy. Jumlah leukosit rerata mencit ( $\left.8,462 \times 10^{3} / \mu \mathrm{l}\right)$ sebelum radiasi dan $\left(7,207 \times 10^{3} / \mu \mathrm{l}\right)$ sesudah radiasi dengan variasi dosis $0,5 \mathrm{~Gy}$ hingga $5 \mathrm{~Gy}$.

Penurunan terbanyak terdapat dipemberian dosis 5 Gy. Dan sedikit penurunan terjadi pada 0,5 Gy. penurunan stabil terjadi di dosis 0,5 Gy hingga 3 Gy. Penurunan terbanyak dan stabil tersebut terjadi di sample darah untuk pemeriksaan hemoglobin dan leukosit. Dan rumus persentase yang didapat dari penurunan jumlah hemoglobin yaitu, $y=0,04 x^{3}-0,497 x^{2}+2,362$ $\mathrm{x}-0,016$ dengan $r=0,990$. Dengan $r$ menunjukkan bahwa hubungan pemberian dosis radiasi terhadap penurunan jumlah hemoglobin sangat kuat.

Untuk persentase selisih jumlah leukosit yaitu,y $=0,080 \mathrm{x}^{3}-1,110 \mathrm{x}^{2}+6,511 \mathrm{x}-2,536$ dengan $r$ $=0,998$. Nilai $r$ menunjukkan bahwa hubungan pemberian dosis radiasi terhadap penurunan jumlah leukosit sangat kuat.Rata-rata persentase total untuk hemoglobin ialah 5,78 \% dan untuk leukosit ialah $14,83 \%$. Di dalam penelitian ini terjadi perbedaan jumlah yang sesuai analisis OneSample $t$ Test yang telah dilakukan di hasil penelitian.Untuk Hemoglobin terlihat bahwa $\mathrm{t}$ hitung adalah $-0,606$ dengan probabilitas 0,560 . Oleh karena probabilitas > 0,05, maka Ho diterima atau ada perbedaan jumlah hemoglobin antara mencit (Mus Musculus) yang diradiasi dan tidak diradiasi.

Untuk Leukosit terlihat bahwa t hitung adalah $-1,790$ dengan probabilitas 0,107. Oleh karena probabilitas $>0,05$, maka Ho diterima atau ada perbedaan jumlah leukosit antara mencit (Mus Musculus) yang diradiasi dan tidak diradiasi.Penurunan jumlah leukosit lebih besar dibanding dengan jumlah hemoglobin, dikarenakan leukosit memiliki tingkat sensitifitas yang sangat tinggi terhadap radiasi.Penurunan jumlah leukosit dapat dijelaskan sebagai berikut, radiasi diketahui mempunyai efek merusak sel-sel induk dan sel-sel prekursor pada sumsum tulang (sindrom sumsum tulang), sehingga menurunkan jumlah sel-sel darah dalam peredarannya. 
Dalam kondisi normal, kehilangan komponen sel darah akibat konsumsi makanan, infeksi maupun umur dapat diimbangi oleh produksi sel darah induk dalam sumsum tulang. Radiasi dapat menghambat aktivitas sel darah induk atau menghentikan aktivitasnya sama sekali, tergantung pada dosis radiasi yang diterimanya. Selain itu sel darah yang bersirkulasi akan mengalami kematian interfase. Dengan demikian, radiasi akan menurunkan jumlah sel darah yang bergantung pada radiosensitivitas dan harapan hidup sel.

Rentang dosis yang diberikan ini masih lebih rendah dari LD 50/30, untuk mencit nilainya sekitar 7 Gy. Menurut definisi LD 50/30 (lethal dose) adalah dosis yang mengakibatkan 50\% populasi mencit mati dalam waktu 30 hari [7]. Interaksi radiasi dengan sel mamalia dapat menginduksi sejumlah besar kerusakaan DNA, seperti single strand breaks (SSB), double strand breaks (DSB), berbagai jenis kerusakan basa, ikatan silang (cross links) DNA, dan kombinasi lokal semua kerusakan tersebut. Kerusakan DNA ini menyebabkan terjadinya mutasi, abrasi kromosom dan perubahan aktivitas, maupun kematian sel.

Jika fungsi hemoglobin turun dalam darah, maka kemungkinan terjadi hal sebagai berikut: yaitu terganggu pengaturan pertukaran oksigen dengan karbondioksida di dalam jaringan tubuh, terganggu pengambilan oksigen dari paru-paru yang dibawa keseluruh jaringan tubuh. Tidak dapat membuang karbondioksida dari jaringan tubuh. Penurunan kadar Hb dari normal berarti kekurangan darah. Kekurangan darah berarti anemia. Ternyata kekurangan Hb juga disertai dengan eritrosit yang berkurang serta nilai hematokrit dibawah normal. Sedangkan jika fungsi leukosit turun makaakan menyebabkan hubungan sistem kekebalan tubuh yang lemah sehingga tidak dapat melawan berbagai penyakit infeksi.

\section{KESIMPULAN}

Dari penelitian perbedaan jumlah hemoglobin dan leukosit sebelum dan sesudah radiasi sinar gamma Co-60 dengan variasi dosis 0,5 Gy hingga 5 Gy pada mencit dapat disimpulkan bahwa jumlah hemoglobin rerata mencit yaitu12,899 $\mathrm{g} / \mathrm{dl}$ sebelum radiasi dan 12,154 g/dl sesudah radiasi dengan variasi dosis 0,5 Gy hingga $5 \mathrm{~Gy}$. Jumlah rerata leukosit mencit $8,462 \times 10^{3} / \mu \mathrm{l}$ sebelum radiasi dan $7,207 \times 10^{3} / \mu 1$ sesudah radiasi dengan variasi dosis 0,5 Gy hingga 5 Gy.Rerata persentase total penurunan jumlah sebelum dan sesudah radiasi untuk hemoglobin ialah 5,78 \% dan untuk leukosit ialah $14,83 \%$. Semakin besar pemberian dosis radiasi, semakin berkurang jumlah hemoglobin dan leukosit. Pada pemberian dosis tunggal $5 \mathrm{~Gy}$, penurunan jumlah hemoglobin dan leukosit terjadi sangat banyak dari jumlah sebelum radiasi. Pada Hemoglobin terlihat bahwa $\mathrm{t}$ hitung adalah $-0,606$ dengan probabilitas 0,560. Oleh karena probabilitas $>0,05$, maka Ho diterima atau ada perbedaan jumlah hemoglobin antara mencit (Mus Musculus) yang diradiasi dan tidak diradiasi. Pada Leukosit terlihat bahwa thitung adalah $-1,790$ dengan probabilitas 0,107 . Oleh karena probabilitas $>0,05$, maka Ho diterima atau ada perbedaan jumlah leukosit antara mencit (Mus Musculus) yang diradiasi dan tidak diradiasi. Jumlah leukosit lebih menurun banyak setelah diradiasi dibanding jumlah hemoglobin, disebabkan leukosit merupakan sel yang tingkat sensitifitasnya lebih tinggi terkena radiasi. Persamaan selisih jumlah hemoglobin dan leukosit sebelum dan sesudah penyinaran gamma Co-60 dengan variasi dosis adalah $Z=\frac{1}{H a}(H a-H b) \times 100 \%$.

\section{REFERENSI}

[1] Hill, R. P.(1994). Cellular Basis of Radiotherapy. In : Tannock IF, HillPH, editors. The Basic Science of Onkology. New York: Mc Graw-HillInc. Company259-275.

[2] Broome, E.J., Brown, D.L., and Mitchel, R.E.J.(2002). Dose Response forAdaptaion to Low Doses of 60Co $\gamma$ and $3 H$ - $\beta$-particle Radiation in NormalHuman Fibroblast. Journal of Radiation. Research. 158, 181-186.

[3] Diklat. (2005). Efek Biologi Radiasi. Diklat Insprektur Pratama Tingkat I,Juli 21.

[4] Akhadi, M.(2000). Dasar - Dasar Proteksi Radiasi. Jakarta : PT. Rineka Cipta.

[5] Diklat. (2005). Efek Biologi Radiasi. Diklat Insprektur Pratama Tingkat I, Juli 21. 
[6] John, B., Smith, B.V.Sc., dan Mangkoewidjojo, S.(1988). Pemeliharaan, Pembiakan, dan Penggunaan Hewan Percobaan di Daerah Tropis. Depok : Universitas Indonesia.

[7] Harahap, N.S.(2008). Pengaruh Aktivitas Fisik Maksimal TerhadapJumlah dan Hitung Jenis Leukosit pada Mencit (Mus Musculus L) Jantan.Sumatera Utara : E-Respository.

[8] Cerveny, T.J., Macvittie, T.J., Young, R.W. (1989). Acute Radiation Syndrome in Humans. Walker, R.I., Cerveny, T.J. Medical consequencesof nuclear warfare. Maryland: TMM Publications, 15-36

[9] Effendi, Z.(2003). Peran Leukosit Sebagai Anti Inflamasi Alergik DalamTubuh. Bagian Histologi Fakultas Kedokteran Universitas Sumatra Utara

[10] Steell, G. G.(1997). Basic Clinical RadiobiologySecond Edition. OxfrordNew York : University Press, Inc.,

[11] BAPETEN. (2011). Surat Keputusan Kepala Bapeten Nomor 8/Ka-Bapeten/11 Tentang Keselamatan Radiasi Dalam Penggunaan Pesawat Sinar-x dan Intervensional. Jakarta: BAPETEN.

[12] Susworo, R.(2007). Radioterapi. Depok : Universitas Indonesia (UI-Press).

[13] Alatas, Z.(1997). Peran Radiobiologi dalam Peningkatan KualitasRadioterapi. Pusat Standardisasi dan Penelitian Keselamatan RadiasiBadan Tenaga Atom Nasional. Buletin ALARA 1 (2), 9-13.

[14] International Atomic Energy Agency.(1981). Protection Against Ionizing Radiation from External Sources Used in Medicine, IAEA Publication 33. Oxford: Pergamon Press

[15] Departemen Kesehatan R.I.(1991). Petunjuk Pemeriksaan Laboratorium Puskesmas.Pusat Laboratorium Kesehatan Ditjen Binkesmas.

[16] Santoso, Singgih.(2003). Mengatasi Berbagai Masalah Statistik dengan SPSS versi 11.5. Jakarta : Elex Media Komputindo. 